\title{
GC-MS Analysis and Biological Activities of Algerian Salvia microphylla Essential Oils
}

\author{
Hafsa Chouit ${ }^{1}$, Ouassila Touafek ${ }^{1 *}$, Moussa Brada ${ }^{2}$, Chawki Benssouici ${ }^{3}$, Marie-Laure Fauconnier ${ }^{4}$, \\ Mohamed El Hattab ${ }^{1}$ \\ ${ }^{1}$ Laboratory of Natural Products Chemistry and Biomolecules, University Blida 1, BP 270 09000, Blida, \\ Algeria. \\ ${ }^{2}$ Valuation of Natural Substances Laboratory, Djilali Bounaama University of Khemis-Miliana, Road of Theniet \\ El-Had, 44225, Algeria. \\ ${ }^{3}$ Biotechnology Research Center (CRBT), Ali Mendjli New Town UV 03, BP E73, Constantine, Algeria. \\ ${ }^{4}$ Laboratory of Chemistry of Natural Molecules, Gembloux Agro-Bio Tech, University of Liège, Passage of \\ Deportees 2, B-5030 Gembloux, Belgium.
}

*Corresponding author: Ouassila Touafek, email: wass_touafek@yahoo.fr

Received May 11 ${ }^{\text {th }}, 2021$; Accepted August $26^{\text {th }}, 2021$.

DOI: http://dx.doi.org/10.29356/jmcs.v65i4.1581

\begin{abstract}
Salvia microphylla is a known species due to its broad uses in traditional medicine against memory loss and rheumatism. The knowledge regarding the chemical composition and biological activities of the species collected in Algeria, no studies have been reported in the literature. Therefore, the present work focuses on the characterization of the chemical composition of the essential oils (EOs) and the determination of the antioxidant, anticholinesterase, $\alpha$-glucosidase, and antimicrobial activities of Salvia microphylla. The EOs were obtained by hydrodistillation from the aerial parts, leaves and stems and submitted to chemical analysis by GC and GC/MS. The $\beta$-Caryophyllene was identified as the main constituent in the aerial parts and leaves essential oils with $16.75 \pm 0.02 \%$ and $17.86 \pm 0.07 \%$, respectively. Likewise, the $\alpha$-Eudesmol was the predominant component in the stems oil with $(21.47 \pm 0.20 \%)$. The antioxidant activity of EOs was estimated through using four comparative methods: DPPH, ABTS•+, Reducing power and CUPRAC assays. The Stems oil was the most active one in CUPRAC assay, with an $\mathrm{IC}_{50}$ value with $7.72 \pm 0.43 \mu \mathrm{g} / \mathrm{mL}$. The enzyme inhibitory activity of the essential oils was realized against key enzymes involved in type 2 diabetes ( $\alpha$-glucosidase) using 4Nitrophenyl- $\alpha$-d-glucopyranoside as substrate and in neurodegenerative (AChE and $\mathrm{BChE}$ ) diseases. The highest anticholinesterase activity against acetylcholinesterase was observed in the $\mathrm{EO}$ of aerial parts essential $\left(\mathrm{IC}_{50}: 23.65 \pm 0.73 \mu \mathrm{g} / \mathrm{mL}\right)$. The EO isolated from stems $\left(\mathrm{IC}_{50}: 37.07 \pm 1.44 \mu \mathrm{g} / \mathrm{mL}\right)$ exhibited a butyrylcholinesterase activity very close to that of analytical standard galantamine $\left(\mathrm{IC}_{50}: 34.75 \pm 1.99 \mu \mathrm{g} / \mathrm{mL}\right)$. Furthermore, all EOs displayed high inhibitory activity against $\alpha$-glucosidase, better to that of the standard acarbose. The EOs of Salvia microphylla display potential properties against type 2 diabetes. A broth microdilution method was used to evaluate the antimicrobial activity of Salvia microphylla EOs, against eleven microbial strains and two yeast. The EOs showed better antibacterial activity against Gram-positive and Gramnegative bacteria except for Pseudomonas aeruginosa, with the stems essential oil being more efficient. Moreover, significant antifungal activity was observed against Candida albicans.
\end{abstract}

Keywords: Salvia microphylla; GC-MS analysis; antioxidant; anticholinesterase; antimicrobial.

Resumen. Salvia microphylla es una specie conocida debido a su amplio uso en medicina tradicional, contra la pérdida de memoria y el reumatismo. En el caso de la especie de planta recolectada en Algeria, no hay datos publicados sobre su composición química y sus actividades biológicas. Por ello, el presente trabajo ha sido 
enfocado en la caracterización de la composición química de aceites esenciales (EOs) de Salvia microphylla y en la determinación de sus actividades antioxidante, anticolinesterasa, $\alpha$-glucosidasa y antimicrobiano. Los EOs fueron obtenidos mediante hidrodestilación de las partes aéreas, ojas y tallos, y fueron sometidos al análisis por cromatografía de gases con detección por ionización en flama y por espectrometría de masas. Se identificó a $\beta$ cariofileno como el componente principal de los aceites de las partes aéreas y de tallos con concentraciones de $16.75 \pm 0.02 \%$ y $17.86 \pm 0.07 \%$, respectivamente. Por su parte, el $\alpha$-Eudesmol fue encontrado como componente predominante en aceite de tallos $(21.47 \pm 0.20 \%)$. La actividad antioxidante de los EOs fue estimada en base a cuatro métodos compartivos: $\mathrm{DPPH}, \mathrm{ABTS} \bullet+$, poder reductor y ensayo CUPRAC. El aceite de tallos resultó ser el más activo en ensayo CUPRAC, con el valor $\mathrm{IC}_{50}$ de $7.72 \pm 0.43 \mu \mathrm{g} / \mathrm{mL}$. La actividad inhibitora de enzimas de los EOs fue evaluada contra principales enzimas involucrados en diabetes tipo 2 ( $\alpha$ glucosidasa), utilizando 4-Nitrofenil- $\alpha$-d-glucopiranosida como sustrato, y en enfermedades neurodergenerativas (AChE y BChE). La mayor actividad anticolinesterasa y acetilcolinesterasa fue observada en el EO de partes aéreas ( $\mathrm{IC}_{50}: 23.65 \pm 0.73 \mu \mathrm{g} / \mathrm{mL}$ ). El EO islado de tallos $\left(\mathrm{IC}_{50}: 37.07 \pm 1.44 \mu \mathrm{g} / \mathrm{mL}\right.$ ) presentó actividad de butirilcolinestarasa muy similar a la del estándar analítico, galantamina $\left(\mathrm{IC}_{50}: 34.75 \pm 1.99 \mu \mathrm{g} / \mathrm{mL}\right)$. Aunado a ello, todos EOs presentaron una alta actividad inhibitora contra $\alpha$-glucosidasa, que era mejor comparando con la del estándar de acarbosa. Los EOs de Salvia microphylla presentan potenciales propiedades contra diabetes tipo 2. Para evaluar la actividad antimicrobiana de los EOs de Salvia microphylla, se utilizó el método de microdulución en caldo, contra once sepas microbianas y dos de levadura. La mejor actividad se observó contra bacterias Gram-positivas y Gram-negativas, excepto Pseudomonas aeruginosa, los cuales presentaron alta resistencia. Los EOs presentaron también importante actividad antifungica contra Candida albicans.

Palabras clave: Salvia microphylla; analisis por cromatografía de gases-espectrometria de masas; antioxidantes; anticolinesterasa; antimicrobiano.

\section{Introduction}

Essential oils are widely used as an alternative medicine in varied industries such as pharmaceutical, agricultural, cosmetic and food industries due to their antiviral, antibacterial, antifungal, antioxidant, antiparasitic, antidiabetic, anticancer, aromatherapy and perfume properties [1]. Lamiaceae is a family of species which is an important source of a wide range of bioactive compounds, it comprised of 236 genera and 6900-7200 species, distributed all over the world. About 900 species of the genus Salvia are represented in five subgenera widespread throughout the world [2]. Nearly, 23 Salvia species cultivated in Algeria, among which S. buchananii, S. jaminiana, S. verbenaca subsp., S. clandestina, S. barrilieri, S. argentea subsp. and $S$. algeriensis Desf., were the subject of various studies [3-5]. Several species of Salvia have been applied as medicinal plants and used, among others, for enhancing memory functions and treatment of simple brain disorders [6], but also, to treat microbial infections, inflammation, malaria, cancer, and to disinfect homes after sickness $[7,8]$. The chemical composition of essential oil of Salvia species was reported in many review papers [5,9-17]. The most important compounds of this essential oil are monoterpenes such as $\alpha$-Pinene, $\beta$-Pinene, camphor, 1.8-cineole and borneol; and sesquiterpenes like $\beta$-Caryophyllene, germacrene D, Caryophyllene oxide. Several investigations on biological activities of various Salvia species revealed the possess spasmolytic, oestrogenic, antimicrobial, antifungal, antioxidant, anticholinesterase and antidiabetic activities of EOs [18-24].

Salvia microphylla is native species originated from Mexico [25], used in the treatment gastrointestinal, central nervous system, gynecology, and obstetrics diseases [26]. In Ecuador, Fresh leaves, and flowers of Salvia microphylla are used to treat inflammation of the arms, feet, and rheumatism [27]. Salvia microphylla is quite easy to grow, it is found in Italy, Spain, Japan, and Turkey. EOs are also valorized for their antimicrobial and antioxidant activities [28]. In addition, the literature has described the insecticidal activity of the n-hexane extracts [29]. In Algeria, this species is used in traditional medicine for some stomach ailments. The literature reports, the principal compounds isolated from Salvia microphylla are phenolic esters, eudesmane-type sesquiterpenes, triterpenes [30], abietane-, clerodane-, neo-clerodane-, microphyllan-, pimarane-type diterpenoids [31-34], $\beta$-sitosterol, ursolic [32] and oleanolic acid [29]. Several studies have been 
carried out on the composition of the essential oil of Salvia microphylla and the results have revealed that $\beta$ caryophyllene and $\alpha$-eudesmol are the major compounds $[28,35,36]$. The chemical composition of the flowers Eos of Salvia microphylla collected in Italy have revealed to be completely different compared to the other parts of the plant, the principal compounds identified are Davana ether, carvacrol and thymol [37]. The present study aims to investigate the chemical composition of the essential oils obtained from aerial parts, leaves, and stems of Salvia microphylla collected in Algeria and to explore the antioxidant and the antimicrobial activities. Furthermore, we evaluate the anti-diabetic and anticholinesterase activities (anti-Alzheimer's activities) of EOs. To the best of our knowledge, no studies have been reported on Salvia microphylla stems and enzyme inhibitory activities (anti-diabetic and anticholinesterase) of the species coming from Algeria.

\section{Experimental}

\section{Materials and methods Solvents and reagents (Chemicals)}

All antioxidant, enzymatic and antibacterial activities measurements were carried out on a 96-well microplate reader, PerkinElmer Multimode Plate Reader EnSpire at National Center of Biotechnology Research.

As regards antiradical tests, the reagents: 2,2-diphenyl-1-picrylhydrazyl (DPPH), butylatedhydroxyanisole (BHA), butylatedhydroxytoluene (BHT), $\alpha$-tocopherol, ascorbic acid, Tannic acid, 2,2'-azinobis(3-ethyl-benzothiazoline-6-sulphonic acid) diammonium salt (ABTS ${ }^{+}$) neocuproine, trichloroacetic acid (TCA), potassium ferricyanide $\left(\mathrm{K}_{3} \mathrm{Fe}(\mathrm{CN})_{6}\right)$ and dimethylsulfoxide (DMSO) were purchased from Sigma Chemical Co. (Sigma-Aldrich $\mathrm{GmbH}$, Sternheim, Germany). Sodium sulphate $\left(\mathrm{Na}_{2} \mathrm{SO}_{4}\right)$, iron(III) chloride $\left(\mathrm{FeCl}_{3}\right)$, copper(II) chloride $\left(\mathrm{CuCl}_{2}\right)$ and ammonium acetate $\left(\mathrm{AcNH}_{4}\right)$ were acquired from Biochem Chemopharma, (France). Regarding enzymatic tests: Acetylthiocholine iodide, SButyrylthiocholine iodide, 5,5'-Dithiobis (2-nitrobenzoic acid) (DTNB), Acetylcholinesterase from electric eel (AChE, Type-VI-S, EC 3.1.1.7, 827,84 U/mg, Sigma), butyrylcholinesterase from horse serum (BChE, EC 3.1.1.8, 7,8 U/mg, Sigma), Galantamine, $\alpha$-Glucosidase from Saccharomyces cerevisiae (Type I, $\geq 10 \mathrm{units} / \mathrm{mg}$ protein), 4-Nitrophenyla-D-glucopyranoside $(\geq 99 \%)$, and Acarbose $(\geq 95 \%)$ were obtained from Sigma Chemical Co. (Sigma-Aldrich GmbH, Stern-Heim, Germany). All other chemicals and solvents were of analytical grade.

\section{Microorganism cultures}

The antibacterial activity of Essential oils were tested against the following microorganisms: Pseudomonas aeruginosa ATCC 25843, Escherichia coli ATCC 25922, Salmonella abony ATCC 14028, Agrobacterium tumefaciens ATCC 23308, Enterobacter cloacae ATCC13047, Enterococcus faecalis ATCC 51299, Micrococcus luteus ATCC 14110, Staphylococcus aureus ATCC 6538, Listeria monocytogenes ATCC 49594, Bacillus subtilis ATCC 6633, Bacillus cereus ATCC 14975, Candida albicans ATCC 1023 and Saccharomyces cerevisiae ATCC 9763. The reference strains (ATCC, American type culture collection) were obtained from the Pasteur Institute (Algiers), using conventional methods by The National Committee for Clinical Laboratory Standards (NCCLS) [38] and the Clinical and Laboratory Standards Institute (CLSI) [39].

\section{Plant material}

During the flowering stage of July (2018), the aerial parts of Salvia microphylla were collected from Blida (Southwest of Algiers, Algeria, latitude: 36 $28^{\prime} 12^{\prime \prime} \mathrm{N}$; longitude: $2^{\circ} 49^{\prime} 39^{\prime \prime} \mathrm{E}$, altitude: $252 \mathrm{~m}$; average temperature: $17.9^{\circ} \mathrm{C}$; average rainfall: $791 \mathrm{~mm}$ ).

Salvia microphylla was identified at the Hamma Botanical Garden, Algiers. A voucher specimen (SmL5/16) was deposited at the herbarium of the Laboratory of Natural Products Chemistry and Biomolecules, University Blida 1. The samples were air-dried in the shade at room temperature for 10 days until constant weight, and subsequently, they are stored in the appropriate conditions until use. 


\section{Essential oils extraction}

A sample of each air-dried part (aerial parts, leaves, stems) of Salvia microphylla was submitted to conventional hydrodistillation using a Clevenger-type apparatus, the plant material $(100 \mathrm{~g})$ was placed in a $2 \mathrm{~L}$ round bottom flask with $2 / 3$ parts $(1300 \mathrm{ml})$ of distilled water, and then extracted for $3 \mathrm{~h}$ after boiling. The different Salvia microphylla EOs obtained were separated from water and stored at $4-5{ }^{\circ} \mathrm{C}$ after removing traces of water by using anhydrous sodium sulphate sulfate $\left(\mathrm{Na}_{2} \mathrm{SO}_{4}\right)$ until analysis.

\section{Essential oils analysis}

The EO was dissolved in hexane at a concentration of $2 \mathrm{mg} / \mathrm{mL}$. The different EOs were analyzed by gas chromatography coupled to a mass spectrometer (GC-MS) and gas chromatography coupled to a flame ionization detector (GC-FID) in order to identify the chemical composition and to determine the mean percentage of compounds, respectively.

\section{Gas chromatography-flame ionization analysis (GC-FID)}

The analysis was carried out by means of an Agilent technology HP GC 6890 system with a flame ionization detector (FID), using a HP-5 capillary column coated with $5 \%$ phenyl-methylsiloxane (30 m x 0.25 $\mathrm{mm} \times 0.25 \mu \mathrm{m}$ film thickness Agilent Technologies, Hewlett-Packard, CA, USA). The temperature program was as follows: $40^{\circ} \mathrm{C}$ during for $1 \mathrm{~min}$, then raised in a first ramp to $200{ }^{\circ} \mathrm{C}$ at $6{ }^{\circ} \mathrm{C} / \mathrm{min}$, followed by a second ramp to $280{ }^{\circ} \mathrm{C}$ at $30^{\circ} \mathrm{C} / \mathrm{min}$, and finally stayed at $280{ }^{\circ} \mathrm{C}$ for 2 minutes. The injection was realized in splitless mode at $280^{\circ} \mathrm{C}$ with a ratio of $1 / 90$; the volume injected was $1 \mu \mathrm{L}$. The detector temperature was fixed at $300{ }^{\circ} \mathrm{C}$, the carrier gas was helium at $1 \mathrm{~mL} / \mathrm{min}$.

\section{Gas chromatography-mass spectrometry analysis (GC-MS)}

The analysis was performed using an Agilent 5973 GC-MS coupled to an Agilent 6890 gas chromatograph fitted with a split-splitless injector at $250^{\circ} \mathrm{C}$. An HP-5MS Agilent capillary column $(30 \mathrm{~m} \times$ $0.25 \mathrm{~mm}, \mathrm{df}=0.25 \mu \mathrm{m}$ ) was used. The analytical conditions were as follows: temperature program: from $40-$ $250{ }^{\circ} \mathrm{C}$ at $6{ }^{\circ} \mathrm{C} / \mathrm{min}$. The carrier gas was helium at $1 \mathrm{~mL} / \mathrm{min}$. The mass spectra have been recorded in EI mode at $70 \mathrm{eV}$, the mass range of $\mathrm{m} / \mathrm{z}: 35$ to $500 \mathrm{amu}$. The source and quadrupole temperatures were fixed at $230{ }^{\circ} \mathrm{C}$ and $150{ }^{\circ} \mathrm{C}$, respectively. The identification of the components was performed on the basis of chromatographic linear retention indices (LRI) and by comparison of the recorded spectra with a computed data library (Wiley 275.L). For sesquiterpene hydrocarbons, further confirmations were obtained by comparing the mass spectra with data from the literature [40,41]. The linear retention indices (LRI) calculations were performed according to Van den Dool and Kratzequation [42], a homologous series of n-alkanes $\left(\mathrm{C}_{7}-\mathrm{C}_{30}\right)$ was injected, under the same chromatographic conditions used for the analysis of the essential oils and used for determining the retention indices of all detected volatile compounds. The Main components have been confirmed by comparison of their retention data with co-injected pure (commercially available) references.

\section{Antioxidant activity}

The antioxidant activity was determined using four comparative methods which are DPPH free radical scavenging assay, $\mathrm{ABTS}^{+}$radical scavenging assay, Cupric reducing antioxidant capacity (CUPRAC) assay and Reducing power assay.

\section{DPPH free radical scavenging assay}

The DPPH radical scavenging was discovered by Goldsmithand Renn in 1922 [43], it was become the most commonly use antioxidant method reported to evaluate the antioxidant capacity of chemical compounds as well as natural products [44,45]. The DPPH radical, which absorb at $517 \mathrm{~nm}$, is reduced to 2,2-diphenyl-1picrylhydrazine (DPPH-H) by means of connecting a hydrogen atom or an electron to the radical center due to the reaction with antioxidant. The method could be used according to literature [46,47]. with some modifications. Thus, $160 \mu 1$ of the methanolic solution of DPPH $(0.1 \mathrm{mM})$ was added to $40 \mu 1$ of the sample solution, dissolved in methanol at various concentrations (EOs and standards). A negative control (Blank solution) was prepared using the methanol in addition to the DPPH reagent. The reaction mixture was incubated at $37^{\circ} \mathrm{C}$ in darkness for $30 \mathrm{~min}$, absorbance was measured using a $96-$ well microplate reader at $517 \mathrm{~nm}$. The 
decrease in the absorbance indicates the augmentation of free radical scavenging activity. The $\alpha$-tocopherol, Butyl hydroxyl toluene (BHT) and Butyl hydroxyanisole (BHA) were used as antioxidant standards for comparison. The free radical scavenging activity of each solution was calculated as percent inhibition according to the following equation. The results were given as $\mathrm{IC}_{50}$ value $(\mu \mathrm{g} / \mathrm{mL})$ corresponding to the concentration of $50 \%$ inhibition:

$$
D P P H \text { scavenging effect }(\%)=\frac{\text { Acontrol }- \text { Asample }}{\text { Acontrol }} \times 100
$$

where, $\mathrm{A}_{\text {control }}$ is the absorbance of the negative control; $\mathrm{A}_{\text {sample }}$ is the absorbance of thereaction mixture, obtained from the microplate reader.

\section{$\mathrm{ABTS}^{+}$radical scavenging assay}

The $\mathrm{ABTS}^{\circ+}$ scavenging activity was carried out using the method described by Re [48], with slight modifications. The $\mathrm{ABTS}^{+}$was produced by the reaction between $7 \mathrm{mM} \mathrm{ABTS}$ in $\mathrm{H}_{2} \mathrm{O}$ and $2.45 \mathrm{mM}$ potassium persulfate, stored in the dark at room temperature for $12 \mathrm{~h}$ to $16 \mathrm{~h}$. The radical cation was stable in this form for more than 2 days when stored in the dark at room temperature. First, the $\mathrm{ABTS}^{\cdot+}$ solution obtained was diluted in methanol or distilled water to obtain the absorbance of $0.700 \pm 0.020$ at $734 \mathrm{~nm}$. Then, $160 \mu 1$ of ABTS $^{*+}$ solution was added to $40 \mu \mathrm{l}$ of the sample solution, dissolved in methanol at various concentrations (EOs and standards). After $10 \mathrm{~min}$ at room temperature, the absorbance was measured using a 96 -well microplate reader at $734 \mathrm{~nm}$. The BHT and BHA were used as antioxidant standards for comparison. The percentage inhibitions were calculated for each concentration relative to a blank absorbance. The scavenging capability of ABTS ++ was calculated using the following equation. The results were given as $\mathrm{IC}_{50}$ value $(\mu \mathrm{g} / \mathrm{mL})$.

$$
\text { ABTS scavenging effect }(\%)=\frac{\text { Acontrol }- \text { Asample }}{\text { Acontrol }} \times 100
$$

where, $A_{\text {Control }}$ is the initial concentration of the $\mathrm{ABTS}^{+}$and $A_{\text {sample }}$ is the absorbance of the remaining concentration of $\mathrm{ABTS}^{+}$in the presence of the sample.

\section{Cupric reducing antioxidant capacity (CUPRAC) assay}

The cupric reducing antioxidant capacity was performed according to literature [49] with minor changes, using a 96-well microplate. A volume of $50 \mu \mathrm{l}$ of $\mathrm{Cu}$ (II) solution $(10 \mathrm{mM})$ was placed in each well, mixed with $50 \mu \mathrm{l}$ of neocuproine solution $(7.5 \mathrm{mM}), 60 \mu \mathrm{l}$ of $\mathrm{AcNH}_{4}$ buffer $(1 \mathrm{M}, \mathrm{pH} 7.0)$ and $40 \mu \mathrm{l}$ of (EOs and standard) at different concentrations levels, as to make the final volume $200 \mu \mathrm{L}$. The resulting mixture was incubated for $1 \mathrm{~h}$ in darkness at room temperature. Then, the absorbance of the solution was measured at 450 $\mathrm{nm}$ against a reagent blank and $\alpha$-tocopherol, BHT and BHA as standards. The results were given as $\mathrm{A}_{0.5}(\mu \mathrm{g} / \mathrm{ml})$ corresponding to the concentration indicating 0.50 absorbances.

\section{Reducing power assay}

The antioxidant was determined as described previously [50] with some modifications. Thus, $10 \mu \mathrm{l}$ of the sample solution at various concentrations, $40 \mu \mathrm{l}$ of phosphate buffer ( $\mathrm{pH}$ 6.6) and $50 \mu \mathrm{l}$ of potassium ferricyanide $\left(\mathrm{K}_{3} \mathrm{Fe}(\mathrm{CN})_{6}\right)(1 \%)$ were mixed and then, incubated at $50{ }^{\circ} \mathrm{C}$ for $20 \mathrm{~min}$. After cooling, the solution was mixed with $50 \mu \mathrm{l}$ of trichloroacetic acid solution (TCA) $(10 \%), 40 \mu \mathrm{l}$ of distilled water and $10 \mu \mathrm{l}$ of ferric chloride solution $(0.1 \%)$. The absorbance was measured at $700 \mathrm{~nm}$ using a 96 -well microplate reader. Tannic acid, ascorbic acid and $\alpha$-tocopherol were used as standards. The results were given as $A_{0.5}(\mu \mathrm{g} / \mathrm{ml})$. Reducing power activity was calculated as follows:

$$
\text { Reducing power activity }(\%)=\left[\left(\frac{\text { Asample }}{\text { Acontrol }}\right)-1\right] \times 100
$$


where, $A_{\text {sample }}$ and $A_{\text {control }}$ are the absorbance of sample and blank solutions, respectively.

\section{Anticholinesterase activity}

The Acetylcholinesterase (AChE) and Butyrylcholinesterase (BChE) inhibitory activity of essential oils was evaluated by slightly modifying the method described by Ellman et al [51], which is based on the reaction of released thiocholine to give a colored product with a chromogenic reagent. Electrophorus electricus $\mathrm{AChE}$ and equine serum $\mathrm{BChE}$ were used, while acetylthiocholine iodide and butyrylthiocholine chloride, respectively, were used as substrates of the reaction. 5,5'-Dithiobis (2-nitrobenzoic acid) (DTNB) and galantamine, respectively, were employed for measurement of the cholinesterase activity and as a positive control (standards). Concisely, $10 \mu \mathrm{l}$ of sample solution (EOs and galantamine) dissolved in methanol at different concentrations was mixed with $150 \mu \mathrm{l}$ of sodium phosphate buffer (100 mM, pH 8.0), $20 \mu \mathrm{AChE}$ $\left(5.32 \times 10^{-3} \mathrm{U}\right)$ or BChE $\left(6.85 \times 10^{-3} \mathrm{U}\right)$ solution and incubated at $25^{\circ} \mathrm{C}$ for $15 \mathrm{~min}$, afterward, $10 \mu \mathrm{l}$ of DTNB $(0.5 \mathrm{mM})$ was added with $10 \mu \mathrm{l}$ of acetylthiocholine iodide $(0.71 \mathrm{mM})$ or butyrylthiocholine chloride $(0.2 \mathrm{mM})$. A 96-well microplate reader was used as spectrophotometric monitoring of the hydrolysis of these substrates by the formation of yellow 5-thio-2- nitrobenzoate anion as the result of the reaction of DTNB with thiocholine, released by the enzymatic hydrolysis of acetylthiocholine iodide or butyrylthiocholine chloride, at a wavelength of $412 \mathrm{~nm}$. The results were given as $\mathrm{IC}_{50}$ value $(\mu \mathrm{g} / \mathrm{mL})$ corresponding to the concentration of $50 \%$ inhibition. The percentage of inhibition of $\mathrm{AChE}$ or $\mathrm{BChE}$ was determined by comparing the reaction rates of the samples relative to a blank sample (ethanol in phosphate buffer $\mathrm{pH} 8$ ) using the formula:

$$
\text { Inhibition }(\%)=\left(\frac{E-S}{E}\right) \times 100
$$

where, $\mathrm{E}$ is the activity of the enzyme without the test sample and $\mathrm{S}$ is the activity of the enzyme with the test sample.

\section{In-vitro Yeast $\alpha$-Glucosidase Inhibition Assay}

The enzymatic assay for $\alpha$-glucosidase was carried out on 96-well microplates according to the method described by Lordan and Amrani [52,53], using p-Nitrophenyl- $\alpha$-d-glucopyranoside (p-NPG) as a substrate. A volume of $50 \mu \mathrm{l}$ of EO solution at different concentrations $(1000 \mu \mathrm{g} / \mathrm{ml}-15,625 \mu \mathrm{g} / \mathrm{ml})$ in $100 \mathrm{mM}$ sodium phosphate buffer (pH 6.9) was mixed with $50 \mu \mathrm{l}$ of $5 \mathrm{mM}$ p-NPG solutions (in phosphate buffer) in a 96-well plate. After incubation at $37^{\circ} \mathrm{C}$ for $5 \mathrm{~min}, 100 \mu \mathrm{l}$ of $0.1 \mathrm{U} / \mathrm{ml} \alpha$-glucosidase from Baker's yeast (in phosphate buffer) was then added to each well. The negative control was prepared without EO and Acarbose was used as positive control (standard). Glucosidase activity was given by measuring the release of p-nitrophenol from pNPG at $405 \mathrm{~nm}$ for $30 \mathrm{~min}$ using a microplate reader set to $37{ }^{\circ} \mathrm{C}$. The results were expressed as the EO concentration that would exhibit a $50 \%$ inhibition of enzyme activity $\left(\mathrm{IC}_{50}\right)$. The inhibition percentage was calculated as follows:

$$
\% \alpha-\text { Glucosidase inhibition activity }=\left(\frac{\text { Absorbance of sample }}{\text { Absorbance of control }}\right) \times 100
$$

\section{Antimicrobial activity assay}

Antimicrobial activity of Salvia microphylla essential oils was tested against five Gram-negative, six Gram-positive bacteria and two yeast. The broth microdilution method was used for the determination of minimum inhibitory concentrations (MIC) in 96-well microplates [54-56]. The tests were performed in Muller Hinton Broth (MHB) for bacteria and Sabouraud Dextrose Broth (SDB) for yeast. The bacterial strains were cultured overnight at $37{ }^{\circ} \mathrm{C}$ in Mueller Hinton Broth (MHB), and the yeasts were cultured overnight at $30{ }^{\circ} \mathrm{C}$ in Sabouraud dextrose broth (SDB).

Serial of double-fold dilutions of EOs in broth medium was prepared aseptically, in a microtiter plate (96 wells). Shortly, $50 \mu \mathrm{L}$ of MHB for bacteria and SDB for yeast were put in each well, successive dilutions were carried out in order to obtain, from the first to the $9^{\text {th }}$ well, a finals concentrations ranging between $0.10-$ 
$26.66 \mu \mathrm{L} / \mathrm{mL}$. Then, each well is inoculated with $50 \mu \mathrm{L}$ of a microbial suspension adjusted to a final optical density (OD) of $0.5 \mathrm{McF}$ arland units (OD at $600 \mathrm{~nm}$ between 0.08 to 0.12 ), corresponding to $1-5 \times 10^{6}$ cells $/ \mathrm{mL}$ for yeast strains and approximately at $1-2 \times 10^{8} \mathrm{UFC} / \mathrm{mL}$ for bacteria. Negative controls were prepared with the culture medium and microorganisms. It must be noticed that the $11^{\text {th }}$ and the $12^{\text {th }}$ wells were reserved for testing that culture medium was sterile and that DMSO, used for emulsifying the EO, did not show any antimicrobial activity, respectively. The microplate was incubated at $37{ }^{\circ} \mathrm{C}$ for 24 hours for bacteria and $26{ }^{\circ} \mathrm{C}$ for 48 hours for yeast. The Growth of the organism in microdilution wells was detected by the unaided eye and by measuring optical density at $600 \mathrm{~nm}$ using a 96-well microplate reader. The well containing the lowest concentration of essential oil in which the microorganism did not show visible growth was classified as the MIC. Amoxicillin and ketoconazole were used as the antibacterial and antifungal positive control.

The minimum bactericidal concentration (MBC) and minimum fungicidal concentration (MFC) of Salvia microphylla essential oils were determined after broth microdilution by sub-culturing of $100 \mu \mathrm{L}$ from wells, yielding a negative microbial growth after incubation on solid medium in Petri dishes with Muller Hinton Agar (MHA) for bacteria and Sabouraud Dextrose Agar (SDA) for yeasts and incubated at $37{ }^{\circ} \mathrm{C}$ for $24 \mathrm{~h}$. The lowest concentration of EO needed to kill $99.9 \%$ of the final inoculum was defined as minimum bactericidal concentration (MBC) or minimum fungicidal concentration (MFC), respectively [57].

\section{Results and discussion}

\section{Extraction yield}

The yields of essential oils of aerial parts, leaves and stems were $0.63 \%(\mathrm{w} / \mathrm{w}), 0.75 \%(\mathrm{w} / \mathrm{w})$ and $0.23 \%(\mathrm{w} / \mathrm{w})$ of dry weight, respectively. The oils obtained were yellow liquids characterized by a strong odor. In comparison to other studies, the aerial parts essential oil yield obtained in the present study was lower than those previously reported for the same species from Italy (3.9\%) [35] and Spain (0.8\%) [58].

The yield variation is due to environmental conditions and geographical origin of the species as well as the hydrodistillation, the plant treatment after harvesting and storage conditions.

\section{Chemical composition of the essential oils}

The chemical analysis of the three essential oils by GC and GC-MS conduct to the identification of 36, 32 , and 47 compounds representing $98.40 \%, 98.55 \%$ and $91.38 \%$ of the total composition from the aerial parts, leaves and stems of Salvia microphylla, respectively.

The chemical composition of the EOs as well as the calculated linear retention index and the ones reported in literature and percentage content are listed in table 1 . The latter reveals that, first, the chemical composition is composed of monoterpenes with about 12-32\% and sesquiterpenes with about 66-78\%, second, the same major compounds are, globally, present in the essential oils of the three parts of Salvia microphylla. Thus, as mentioned in table 1, the content of the main compounds presents in EOs of Aerial parts (Fig.1 (A)), Leaves (Fig.1 (B)) and Stems (Fig.1 (C)) are, respectively, the monoterpenes 1,8-cinéole $(5.87 \%, 7.50 \%$, $1.98 \%)$, Bornyl acetate $(8.14 \%, 8.35 \%, 5.18 \%)$ and the sesquiterpenes $\beta$-Caryophyllene $(16.75 \%, 17.86 \%$, $15.65 \%)$, Aromadendrene (5.39\%, $5.30 \%, 4.90 \%)$, Spathulenol (5.04 \%, 4.30\%, $5.12 \%), \gamma$-Eudesmol $(6.27 \%, 5.93 \%, 7.43 \%)$, $\beta$-Eudesmol (6.04 \%, $6.05 \%, 0$ \%), $\alpha$-Eudesmol (11.41 \%, $9.86 \%, 21.47 \%)$.

it must be highlighted that Diterpenes (Abietatriene, Ferruginol) was detected only in Stems essential oil with a lower percentage $(0.44 \%)$. Whereas sesquiterpenes have the same content in aerial part and leaves EOs with about $65 \%$, however, their content is around $80 \%$ in the stems. It seems that the stems privileged the biosynthesis of sesquiterpenes probably for their great exposure to the sun.

The main compounds are almost present in all three parts of the plant. Except for $\beta$-Eudesmol which is in high proportion in the aerial parts and the leaves while it is completely absent in the stems. $\beta$-Caryophyllene and $\alpha$-Eudesmol are the major sesquiterpenes in the three EOs. However, the content of $\beta$-Caryophyllene is high in the three parts of the plant while $\alpha$-Eudesmol is present in the stems with a content of $21.4 \%$ and relatively low in the aerial parts and leaves. This predominance of ' $\alpha$-Eudesmol in the stems EO was qualitatively similar to already published data [36] for the aerial parts of Salvia microphylla from Greece with, a high content of $\alpha$-eudesmol (20.5\%), $\beta$-caryophyllene (13.7\%), $\gamma$-Eudesmol (8.2\%), Spathulenol (7.0 \%). 
These differences reported in essential oil compositions are probably due to several parameters such as the origin of the material, the period of harvest, the part of the plant and the isolation method of the essential oil.

Some studies reported in the literature has shown that $\beta$-Caryophyllene $(10.80 \%)$, bornyl acetate $(9.13 \%), 1,8$-cinéole $(8.43 \%), \alpha$-eudesmol $(6.41 \%), \alpha$-pinene $(5.89 \%)$, camphene $(5.31 \%)$ and $\beta$-eudesmol $(5.27 \%)$ were the main components in essential oils isolated from aerial parts of Salvia microphylla from Italy [35]. In another study, Salvia microphylla grown in Brazil was characterized by the presence of $\beta$-caryophyllene (15.35\%), $\alpha$-eudesmol (14.06\%), $\beta$-eudesmol (8.74\%), $\gamma$-eudesmol (7.64 \%) and Bicyclogermacrene $(6.17 \%)$ as the major compounds isolated from leaves [28].

Comparison between the composition of Salvia microphylla essential oil, not previously reported from Algeria and the literature data show that the predominance of $\beta$-caryophyllene, in our sample was similar to those reported in the literature $[28,35]$. It therefore seems that biosynthesis within the species promotes the formation of $\beta$-Caryophyllene which could be used as a biomarker in chemotaxonomy or to identify the species' chemotype.

Table 1. Chemical composition of the essential oils isolated from aerial parts leaves and stems of Salvia microphylla

\begin{tabular}{|c|c|c|c|c|c|c|c|}
\hline \multirow{2}{*}{ No. } & \multirow{2}{*}{ compounds $^{a}$} & \multirow{2}{*}{ Class } & \multirow{2}{*}{$\mathbf{L R I}_{\text {cal }}{ }^{b}$} & \multirow{2}{*}{ LRI $_{\text {Lit }}{ }^{c}$} & \multicolumn{3}{|c|}{ Percent content $(\%)^{d}$} \\
\hline & & & & & Aerial parts & Leaves & Stems \\
\hline 1 & $\alpha$-Thujene & $\mathrm{mh}$ & 927 & 925 & $\operatorname{Tr}$ & $\operatorname{Tr}$ & - \\
\hline 2 & $\alpha$-Pinene & $\mathrm{mh}$ & 933 & 939 & $4.09 \pm 0.01$ & $4.63 \pm 0.02$ & $0.91 \pm 0.04$ \\
\hline 3 & Camphene & $\mathrm{mh}$ & 947 & 951 & $4.04 \pm 0.02$ & $4.48 \pm 0.03$ & $0.94 \pm 0.14$ \\
\hline 4 & $\beta$-Pinene & $\mathrm{mh}$ & 976 & 978 & $2.29 \pm 0.01$ & $2.63 \pm 0.03$ & $0.76 \pm 0.04$ \\
\hline 5 & $\alpha$-Terpinene & $\mathrm{mh}$ & 1017 & 1017 & - & - & $\operatorname{Tr}$ \\
\hline 6 & p-Cymene & $\mathrm{mh}$ & 1026 & 1026 & $\operatorname{Tr}$ & $\operatorname{Tr}$ & $\operatorname{Tr}$ \\
\hline 7 & $\beta$-Phellandrene & $\mathrm{mh}$ & 1028 & 1045 & $1.65 \pm 0.01$ & $1.99 \pm 0.09$ & $0.92 \pm 0.07$ \\
\hline 8 & 1,8-cinéole & om & 1030 & 1046 & $5.87 \pm 0.02$ & $7.50 \pm 0.01$ & $1.98 \pm 0.10$ \\
\hline 9 & $\gamma$-Terpinene & $\mathrm{mh}$ & 1058 & 1060 & $\operatorname{Tr}$ & $\operatorname{Tr}$ & $0.39 \pm 0.09$ \\
\hline 10 & $\alpha$-Thujone & om & 1105 & 1105 & - & - & $\operatorname{Tr}$ \\
\hline 11 & Camphor & om & 1144 & 1145 & $2.61 \pm 0.01$ & $2.58 \pm 0.18$ & $1.10 \pm 0.05$ \\
\hline 12 & Borneol & om & 1166 & 1166 & $\operatorname{Tr}$ & $\operatorname{Tr}$ & $0.37 \pm 0.02$ \\
\hline 13 & Terpinen-4-ol & om & 1178 & 1177 & $\operatorname{Tr}$ & - & $\operatorname{Tr}$ \\
\hline 14 & Pregeijerene B & om & 1275 & 1276 & - & - & $\operatorname{Tr}$ \\
\hline 15 & Bornyl acetate & om & 1288 & 1287 & $8.14 \pm 0.02$ & $8.35 \pm 0.05$ & $5.18 \pm 0.12$ \\
\hline 16 & $\alpha$-Cubebene & $\mathrm{sh}$ & 1351 & 1351 & - & - & $\operatorname{Tr}$ \\
\hline 17 & Isoledene & $\mathrm{sh}$ & 1374 & 1374 & - & - & $\operatorname{Tr}$ \\
\hline 18 & $\alpha$-Copaene & sh & 1378 & 1376 & $\operatorname{Tr}$ & $\operatorname{Tr}$ & $0.37 \pm 0.03$ \\
\hline 19 & $\beta$-Bourbonene & sh & 1387 & 1384 & - & - & $\operatorname{Tr}$ \\
\hline 20 & $\beta$-Cubebene & sh & 1392 & 1388 & - & - & $\operatorname{Tr}$ \\
\hline 21 & $\alpha$-Gurjunene & sh & 1412 & 1408 & $1.01 \pm 0.01$ & $1.19 \pm 0.03$ & $1.08 \pm 0.08$ \\
\hline 22 & $\beta$-Caryophyllene & $\mathrm{sh}$ & 1426 & 1417 & $16.75 \pm 0.02$ & $17.86 \pm 0.07$ & $15.65 \pm 0.16$ \\
\hline 23 & $\gamma$-Maaliene & $\mathrm{sh}$ & 1432 & 1430 & $0.67 \pm 0.01$ & $\operatorname{Tr}$ & $0.65 \pm 0.05$ \\
\hline 24 & Calarene & sh & 1436 & 1433 & $\operatorname{Tr}$ & $\operatorname{Tr}$ & $0.41 \pm 0.07$ \\
\hline 25 & $\alpha$-Maaliene & sh & 1438 & 1438 & $0.69 \pm 0.01$ & $\operatorname{Tr}$ & $0.65 \pm 0.10$ \\
\hline
\end{tabular}




\begin{tabular}{|c|c|c|c|c|c|c|c|}
\hline 26 & Aromadendrene & sh & 1444 & 1441 & $5.39 \pm 0.01$ & $5.30 \pm 0.05$ & $4.90 \pm 0.08$ \\
\hline 27 & Selina-5.11-diene & $\mathrm{sh}$ & 1447 & 1445 & $\operatorname{Tr}$ & - & $0.54 \pm 0.10$ \\
\hline 28 & $\alpha$-Humulene & sh & 1457 & 1452 & $0.92 \pm 0.01$ & $0.95 \pm 0.05$ & $0.94 \pm 0.07$ \\
\hline 29 & 9-epi-(E)-Caryophyllene & sh & 1462 & 1464 & - & - & $0.35 \pm 0.04$ \\
\hline 30 & allo-Aromadendrene & sh & 1465 & 1467 & $2.02 \pm 0.01$ & $1.98 \pm 0.18$ & $1.63 \pm 0.02$ \\
\hline 31 & $\gamma$-Muurolene & sh & 1479 & 1474 & $\operatorname{Tr}$ & $\operatorname{Tr}$ & $0.63 \pm 0.03$ \\
\hline 32 & $\beta$-Selinene & $\mathrm{sh}$ & 1490 & 1489 & $\operatorname{Tr}$ & - & $0.33 \pm 0.05$ \\
\hline 33 & Bicyclogermacrene & sh & 1502 & 1499 & $3.65 \pm 0.01$ & $4.15 \pm 0.08$ & $5.02 \pm 0.12$ \\
\hline 34 & $\gamma$-Cadinene & sh & 1518 & 1511 & $1.28 \pm 0.01$ & $1.22 \pm 0.04$ & $1.45 \pm 0.04$ \\
\hline 35 & $\delta$-Cadinene & $\mathrm{sh}$ & 1527 & 1519 & $1.98 \pm 0.01$ & $2.11 \pm 0.02$ & $1.84 \pm 0.14$ \\
\hline 36 & Trans Cadi-1.4-diene & sh & 1536 & 1527 & - & - & $\operatorname{Tr}$ \\
\hline 37 & $\alpha$-Cadinene & sh & 1541 & 1538 & - & - & $\operatorname{Tr}$ \\
\hline 38 & $\alpha$-Calacorene & $\mathrm{sh}$ & 1547 & 1542 & - & - & $\operatorname{Tr}$ \\
\hline 39 & Epiglobulol & os & 1565 & 1554 & $\operatorname{Tr}$ & - & $0.36 \pm 0.05$ \\
\hline 40 & Spathulenol & os & 1586 & 1571 & $5.04 \pm 0.02$ & $4.30 \pm 0.23$ & $5.12 \pm 0.13$ \\
\hline 41 & Caryophyllene oxide & os & 1591 & 1582 & $3.26 \pm 0.01$ & $3.02 \pm 0.02$ & $2.94 \pm 0.09$ \\
\hline 42 & Viridiflorol & os & 1598 & 1592 & $\operatorname{Tr}$ & $\operatorname{Tr}$ & $0.57 \pm 0.04$ \\
\hline 43 & Rosifoliol & os & 1609 & 1603 & $0.65 \pm 0.01$ & $\operatorname{Tr}$ & $0.82 \pm 0.05$ \\
\hline 44 & $\gamma$-Eudesmol & os & 1640 & 1630 & $6.27 \pm 0.02$ & $5.93 \pm 0.15$ & $7.43 \pm 0.04$ \\
\hline 45 & T-Cadinol & os & 1647 & 1645 & $2.68 \pm 0.02$ & $2.47 \pm 0.18$ & $3.23 \pm 0.15$ \\
\hline 46 & $\beta$-Eudesmol & os & 1663 & 1650 & $6.04 \pm 0.24$ & $6.05 \pm 0.05$ & - \\
\hline 47 & $\alpha$-Eudesmol & os & 1667 & 1652 & $11.41 \pm 0.27$ & $9.86 \pm 0.24$ & $21.47 \pm 0.20$ \\
\hline 48 & Abietatriene & dh & 2064 & 2054 & - & - & $0.25 \pm 0.02$ \\
\hline 49 & Ferruginol & od & 2338 & 2332 & - & - & $0.19 \pm 0.03$ \\
\hline \multicolumn{5}{|c|}{ Class of compounds } & Aerial parts & Leaves & Stems \\
\hline \multicolumn{5}{|c|}{ Monoterpene hydrocarbons (mh) } & 12.08 & 13.73 & 3.93 \\
\hline \multicolumn{5}{|c|}{ Oxygenated monoterpenes (om) } & 16.63 & 18.43 & 8.63 \\
\hline \multicolumn{5}{|c|}{ Sesquiterpene hydrocarbons (sh) } & 34.34 & 34.76 & 36.44 \\
\hline \multicolumn{5}{|c|}{ Oxygenated sesquiterpenes (os) } & 35.36 & 31.63 & 41.94 \\
\hline \multicolumn{5}{|c|}{ diterpenes hydrocarbons (dh) } & - & - & 0.25 \\
\hline \multicolumn{5}{|c|}{ Oxygenated diterpenes (od) } & - & - & 0.19 \\
\hline \multicolumn{5}{|c|}{ Total Identified (\%) } & 98.40 & 98.55 & 91.38 \\
\hline
\end{tabular}

Tr: traces $(<0.1 \%)$.

${ }^{a}$ Compounds listed in order of elution from HP-5MS capillary column.

${ }^{b}$ Relative retention indices to $\mathrm{C}_{8}-\mathrm{C}_{28} \mathrm{n}$-alkanes on HP-5MS capillary column.

${ }^{\mathrm{c}}$ Literature retention indices.

${ }^{d}$ Values are mean $\pm \mathrm{SD}$ of three injections. 

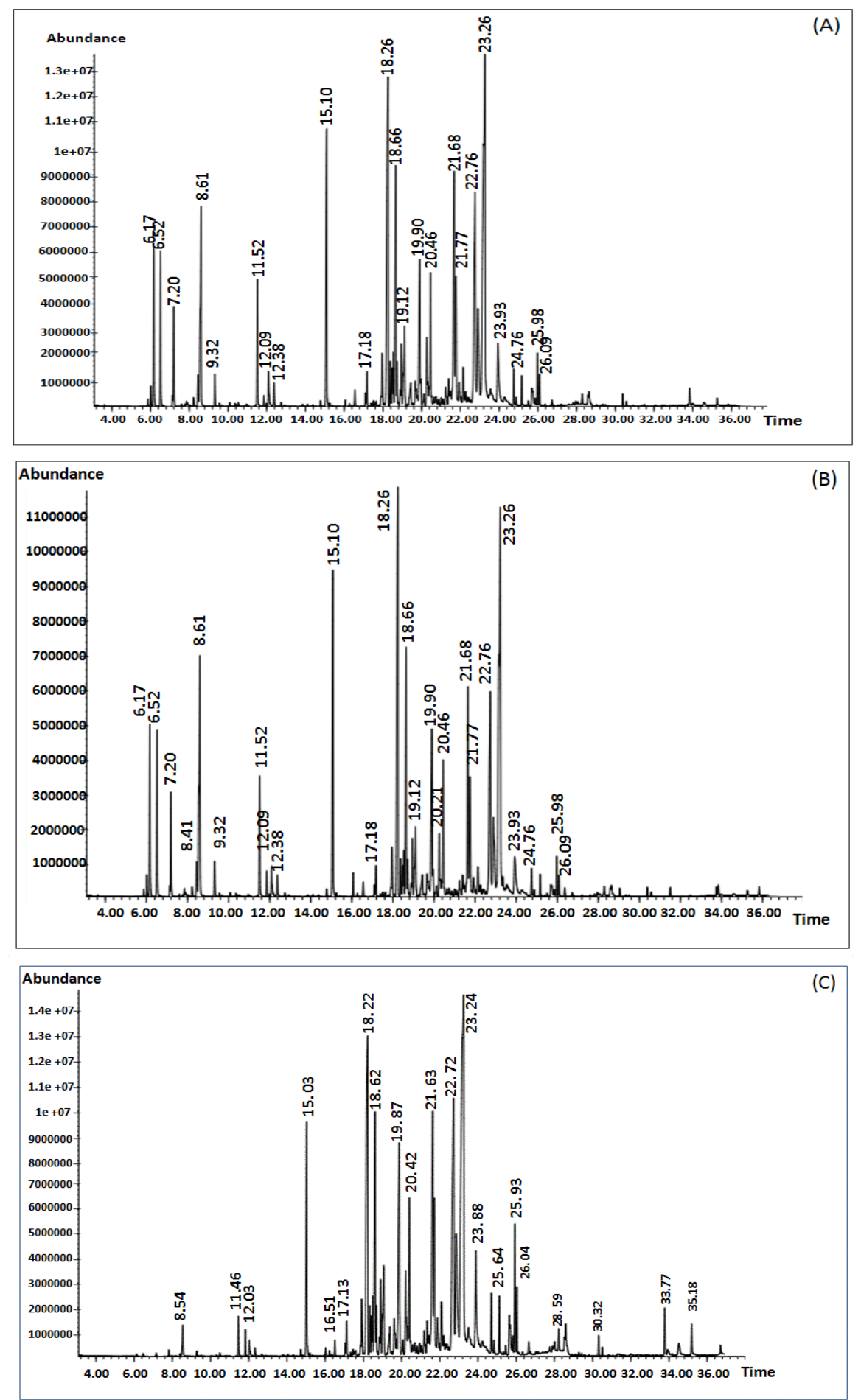

Fig. 1. GC chromatogram of Salvia microphylla; Aerial parts essential oil (A), Leaves essential oil (B), Stems essential oil (C). 


\section{Antioxidant activity}

Antioxidant activity of essential oils extracted by hydrodistillation from aerial parts, leaves and stems of Salvia microphylla has been determined by four different test systems, namely, the DPPH scavenging, ABTS cation radical, cupric reducing antioxidant capacity and Reducing power. The results of antioxidant activity are expressed as terms of $\mathrm{IC}_{50}(\mu \mathrm{g} / \mathrm{mL}), \mathrm{A}_{0.5}(\mu \mathrm{g} / \mathrm{mL})$ and are given in table 2 . For the CUPRAC assay, the best $\mathrm{IC}_{50}$ was found for the stems essential oil $\left(\mathrm{IC}_{50}: 7.72 \pm 0.43 \mu \mathrm{g} / \mathrm{mL}\right.$ ), the recorded activity was very closer to BHA ( $\left(\mathrm{IC}_{50}: 5.35 \pm 0.71 \mu \mathrm{g} / \mathrm{mL}\right.$ ) and better than the one of $\alpha$-tocopherol and BHT $\left(\mathrm{IC}_{50}: 19.92 \pm 1.46 \mu \mathrm{g} / \mathrm{mL}\right.$ and $8.97 \pm 3.94 \mu \mathrm{g} / \mathrm{mL}$, respectively), it was followed by the aerial parts ( $\mathrm{IC}_{50}: 472.02 \pm 5.18 \mu \mathrm{g} / \mathrm{mL}$ ) and leaves EOs ( $\mathrm{IC}_{50}: 504.80 \pm 6.06 \mu \mathrm{g} / \mathrm{mL}$ ). The activities values obtained was different compared with the one of DPPH assay, ABTS assay and reducing power. According to the results acquired using the DPPH assay, ABTS assay, and reducing power methods, the essential oils of the three parts of Salvia microphylla did not exhibit any activity. Our results are in agreement with those of previous works, who reported that the leaves essential oil did not give any activity by DPPH assay [28]. The DPPH scavenging assay is not applicable for the evaluation of the antioxidant activities of essential oils, due to the low solubility of these oils in the DPPH medium $[28,59]$. The antioxidant activity of aerial parts and stems essential oils of Salvia microphylla has not been reported in the literature. The antioxidant activities of sesquiterpenes (major compounds in Salvia microphylla), such as Sesquiterpene hydrocarbons $\beta$-caryophyllene, aromadendrene, and $\alpha$-Humulene, as well as the Oxygenated sesquiterpenes $\alpha$-eudesmol, $\gamma$-eudesmol and Caryophyllene oxide were significantly lower than the one of some monocyclic monoterpenes (a minor compound in Salvia microphylla). Globally, the cyclic alcohols, including globulol, $\alpha$-terpineol and terpin-4-ol have lower antioxidant activity than that of acyclic alcohols, such as $\alpha$ bisabolol, nerol and geraniol [60]. Therefore, this important activity of Stems sample by CUPRAC assay compared to other samples was probably due to the specificity of cupric ion reducing and the positive interactions between both major and minor constituents [13].

\section{Anticholinesterase activity}

Previous studies on Salvia species showed that essentials oils are used traditionally for various nervous system disorders and have potential therapeutic effects on mood and cognitive functions through cholinesterase inhibition which could be attributed to terpenes [61-63]. The anticholinesterase activity of essential oils from different parts (aerial parts, leaves and stems) of Salvia microphylla was tested using a combination of two complementary methods systems acetylcholinesterase ( $\mathrm{AChE}$ ) and butyrylcholinesterase (BChE). The results for $\mathrm{AChE}$ and $\mathrm{BChE}$ inhibition expressed in terms of percentage of inhibition and $\mathrm{IC}_{50}$ are shown in table 3 and 4 , respectively.

In the AChE inhibition assay, the essential oil of aerial parts of Salvia microphylla exhibited the highest inhibitory activity $\left(\mathrm{IC}_{50}: 23.65 \pm 0.73 \mu \mathrm{g} / \mathrm{mL}\right.$ ), closer activity to that of standard galantamine $\left(\mathrm{IC}_{50}: 6.27 \pm 1.15\right.$ $\mu \mathrm{g} / \mathrm{mL}$ ), followed by leaves essential oil ( $\mathrm{IC}_{50}: 125.56 \pm 0.32 \mu \mathrm{g} / \mathrm{mL}$ ) and stems essential oil ( $\mathrm{IC}_{50}: 159.28 \pm$ $2.13 \mu \mathrm{g} / \mathrm{mL}$ ). These results are in good agreement with the results obtained from the essential oil of Salvia pseudeuphratica, with $\left(\mathrm{IC}_{50}: 26.00 \pm 2.00 \mu \mathrm{g} / \mathrm{mL}\right)$ in $\mathrm{AChE}$ [15]. Although, this is the first report on the anticholinesterase activity of Salvia microphylla. From literature reports, essential oils of other species from the genus Salvia also exhibited a notable inhibition of AChE [5,16,17,64-67]. Some studies have demonstrated that AChE enzyme inhibitory effect of essential oil derived from poor camphor containing Salvia officinalis was lower than essential oils rich in camphor content $[15,65]$. Consequently, aerial parts essential oil of Salvia microphylla could be ideal for AChE inhibition with a high level of camphor $(2.61 \pm 0.01 \%)$ compared to essential oil extracted from stems $(1.10 \pm 0.05 \%)$. These findings show that camphor may be responsible for inhibitory effect on the AChE enzyme.

A combination of camphor and 1,8-cineole may result with either synergy or antagonism [15,68]. Our study for leaves essential oil has shown that AChE inhibition is low compared to aerial parts essential oil. Although the essential oils of the aerial parts and leaves have almost the same amount of camphor $(2.61 \pm$ $0.01 \%$ and $2.58 \pm 0.18 \%$, respectively). The low level of AChE inhibition of leaves essential oil is probably due to antagonistic interactions of these essential oil components. 
Table 2. Antioxidant activities of essential oils of Salvia microphylla aerial parts, leaves and stems by DPPH ${ }^{*} \mathrm{ABTS}^{++}$CUPRAC and reducing power.

\begin{tabular}{|c|c|c|c|c|c|c|c|c|}
\hline \multirow{2}{*}{ Samples } & \multicolumn{2}{|c|}{ DPPH• assay } & \multicolumn{2}{|c|}{ ABTS $^{\circ+}$ assay } & \multicolumn{2}{|c|}{ CUPRAC assay } & \multicolumn{2}{|c|}{ Reducing power assay } \\
\hline & IP (\%) & $\mathrm{IC}_{50} \mu \mathrm{g} / \mathrm{mL}$ & IP (\%) & $\mathrm{IC}_{50} \mu \mathrm{g} / \mathrm{mL}$ & IP (\%) & $A_{0.50} \mu \mathrm{g} / \mathrm{mL}$ & IP (\%) & $A_{0.50} \mu \mathrm{g} / \mathrm{mL}$ \\
\hline Aerial parts & $16.11 \pm 5.34$ & $>800$ & $12.83 \pm 1.32$ & $>800$ & $0.72 \pm 0.07$ & $472.02 \pm 5.18$ & $0.14 \pm 0.03$ & $>200$ \\
\hline Leaves & $16.51 \pm 0.26$ & $>800$ & $10.01 \pm 0.11$ & $>800$ & $0.69 \pm 0.03$ & $504.80 \pm 6.06$ & NA & $>200$ \\
\hline Stems & $26.82 \pm 1.15$ & $>800$ & $21.21 \pm 1.31$ & $>800$ & $3.25 \pm 0.07$ & $7.72 \pm 0.43$ & NA & $>200$ \\
\hline BHA & $90.14 \pm 0.00$ & $6.14 \pm 0.41$ & $95.86 \pm 0.10$ & $1.81 \pm 0.10$ & $3.92 \pm 0.13$ & $5.35 \pm 0.71$ & - & - \\
\hline BHT & $95.02 \pm 0.23$ & $12.99 \pm 0.41$ & $96.68 \pm 0.39$ & $1.29 \pm 0.30$ & $3.38 \pm 0.13$ & $8.97 \pm 3.94$ & - & - \\
\hline$\alpha$-Tocopherol & $89.52 \pm 0.33$ & $13.02 \pm 5.17$ & - & - & $1.85 \pm 0.19$ & $19.92 \pm 1.46$ & $1.81 \pm 0.09$ & $34.93 \pm 2.38$ \\
\hline Ascrobic acid & - & - & - & - & - & - & $1.44 \pm 0.21$ & $6.77 \pm 1.15$ \\
\hline Tannic acid & - & - & - & - & - & - & $1.02 \pm 0.13$ & $5.39 \pm 0.91$ \\
\hline
\end{tabular}

$I P$ : Inhibition percentage at a final concentration of $800 \mu \mathrm{g} / \mathrm{mL}$ for DPPH ${ }^{*}, \mathrm{ABTS}^{*+}$, CUPRAC and $200 \mu \mathrm{g} / \mathrm{mL}$ for Reducing power in the well.

$\mathrm{IC}_{50}$ and $\mathrm{A}_{0.50}$ values are defined as the concentration of $50 \%$ inhibition percentages and the concentration at 0.50 absorbance, respectively. IC 50 and $\mathrm{A}_{0.50}$ were calculated by linear regression analysis and expressed as Mean \pm S.D of three parallel measurements.

BHA: butylatedhydroxyanisole.

$B H T$ : butylatedhydroxytoluene.

$N A$ : not absorbance.

Table 3. Acetylcholinesterase inhibitory activity of essential oils of Salvia microphylla aerial parts, leaves and stems.

\begin{tabular}{|c|c|c|c|c|c|c|c|c|}
\hline \multirow{2}{*}{ Samples } & \multicolumn{8}{|c|}{ Acetylcholinesterase inhibitory activity } \\
\cline { 2 - 8 } & $\mathbf{3 . 1 2 5} \boldsymbol{\mu g} / \mathbf{m l}$ & $\mathbf{6 . 2 5} \boldsymbol{\mu g} / \mathbf{m l}$ & $\mathbf{1 2 . 5} \boldsymbol{\mu g} / \mathbf{m l}$ & $\mathbf{2 5} \boldsymbol{\mu g} / \mathbf{m l}$ & $\mathbf{5 0} \boldsymbol{\mu g} / \mathbf{m l}$ & $\mathbf{1 0 0} \boldsymbol{\mu g} / \mathbf{m l}$ & $\mathbf{2 0 0} \boldsymbol{\mu g} / \mathbf{m l}$ & $\mathbf{I C} \mathbf{5 0} \boldsymbol{\mu g} / \mathbf{m L}$ \\
\hline Aerial parts & $15.41 \pm 2.59$ & $25.78 \pm 1.86$ & $37.70 \pm 1.29$ & $54.77 \pm 2.34$ & $80.38 \pm 3.15$ & NT & NT & $\mathbf{2 3 . 6 5} \pm \mathbf{0 . 7 3}$ \\
\hline Leaves & NA & NA & NA & NA & $20.93 \pm 2.53$ & $36.51 \pm 2.10$ & $72.72 \pm 2.24$ & $\mathbf{1 2 5 . 5 6} \pm \mathbf{0 . 3 2}$ \\
\hline Stems & NA & NA & NA & NA & $26.77 \pm 3.98$ & $47.25 \pm 3.29$ & $56.81 \pm 1.02$ & $\mathbf{1 5 9 . 2 8} \pm \mathbf{2 . 1 3}$ \\
\hline Galantamine $^{\mathrm{R}}$ & $35.93 \pm 2.28$ & $43.77 \pm 0.00$ & $68.50 \pm 0.31$ & $80.69 \pm 0.41$ & $85.78 \pm 1.630$ & $91.80 \pm 0.2$ & $94.77 \pm 0.34$ & $\mathbf{6 . 2 7} \pm \mathbf{1 . 1 5}$ \\
\hline
\end{tabular}

$\mathrm{IC}_{50}$ values are defined as the concentration of $50 \%$ inhibition percentages and calculated by linear regression analysis and expressed as Mean \pm S.D of three parallel measurements.

$R$ : reference compounds. NT: not tested. NA: not absorbance. 
Table 4. Butyrylcholinesterase inhibitory activity of essential oils of Salvia microphyllaaerial parts, leaves and stems.

\begin{tabular}{|c|c|c|c|c|c|c|c|c|}
\hline \multirow{2}{*}{ Samples } & \multicolumn{7}{|c|}{ Butyrylcholinesterase inhibitory activity } \\
\cline { 2 - 10 } & $\begin{array}{c}\mathbf{3 . 1 2 5} \\
\mathbf{\mu g} / \mathbf{m l}\end{array}$ & $\mathbf{6 . 2 5} \boldsymbol{\mu g} / \mathbf{m l}$ & $\mathbf{1 2 . 5} \boldsymbol{\mu g} / \mathbf{m l}$ & $\mathbf{2 5} \boldsymbol{\mu g} / \mathbf{m l}$ & $\mathbf{5 0} \boldsymbol{\mu g} / \mathbf{m l}$ & $\mathbf{1 0 0} \boldsymbol{\mu g} / \mathbf{m l}$ & $\mathbf{2 0 0} \boldsymbol{\mu g} / \mathbf{m l}$ & $\mathbf{I C} \mathbf{5 0} \boldsymbol{\mu g} / \mathbf{m L}$ \\
\hline Aerial parts & $9.50 \pm 2.88$ & $12.21 \pm 2.19$ & $20.40 \pm 0.35$ & $27.81 \pm 0.81$ & $42.21 \pm 1.38$ & $59.41 \pm 0.23$ & $65.82 \pm 1.50$ & $\mathbf{6 9 . 6 5} \pm \mathbf{0 . 8 7}$ \\
\hline Leaves & $8.37 \pm 3.95$ & $13.04 \pm 3.92$ & $27.93 \pm 8.31$ & $35.59 \pm 0.25$ & $50.57 \pm 0.63$ & $58.85 \pm 1.19$ & $66.87 \pm 3.61$ & $\mathbf{4 8 . 5 4} \pm \mathbf{0 . 6 7}$ \\
\hline Stems & $11.99 \pm 5.96$ & $16.81 \pm 3.06$ & $23.50 \pm 2.31$ & $41.45 \pm 1.49$ & $60.23 \pm 1.63$ & $70.87 \pm 0.75$ & $78.41 \pm 0.68$ & $\mathbf{3 7 . 0 7} \pm \mathbf{1 . 4 4}$ \\
\hline Galantamine $^{\mathrm{R}}$ & $3.26 \pm 0.62$ & $6.93 \pm 0.62$ & $24.03 \pm 2.94$ & $45.13 \pm 2.60$ & $63.87 \pm 2.85$ & $73.57 \pm 0.77$ & $78.95 \pm 0.58$ & $\mathbf{3 4 . 7 5} \pm \mathbf{1 . 9 9}$ \\
\hline
\end{tabular}


The essential oils from stems $\left(\mathrm{IC}_{50}: 37.07 \pm 1.44 \mu \mathrm{g} / \mathrm{mL}\right.$ ) showed the highest inhibitory activity against $\mathrm{BChE}$, even similar to galantamine ( $\mathrm{IC}_{50}: 34.75 \pm 1.99 \mu \mathrm{g} / \mathrm{mL}$ ) and followed by essential oils from leaves and aerial parts ( $\mathrm{IC}_{50}: 48.54 \pm 0.67 \mu \mathrm{g} / \mathrm{mL}$ and $69.65 \pm 0.87 \mu \mathrm{g} / \mathrm{mL}$, respectively). In comparison to previous studies, the BChE inhibition activity of Salvia microphylla was similar to/or higher than other Salvia species reported in the literature $[5,10,15,66,67]$. Some studies reported that 1,8 -cineole has an inhibitory on BChE activity ( IC $_{50}$ : $0.93 \mathrm{mM}$ ). However, camphor did not show an inhibitory effect even at the highest tested concentration (10 $\mathrm{mM}$ ) [15, 69]. According to literature review and the present result, it appears that 1,8-cineole could have a role in the inhibitory effect of aerial parts $(5.87 \pm 0.02 \%)$ and leaves $(7.50 \pm 0.01 \%)$ Eos of Salvia microphylla. While the 1,8-cineole content in the stems essential oil $(1.98 \pm 0.10 \%)$ is lower compared to the other parts. The high level of BChE inhibition of stems essential oil is probably due to synergistic chemical interactions of these essential oil components $[15,68]$. These results may justify the traditional use of Salvia essential oils for failing memory.

\section{a-Glucosidase inhibitory activity}

Diabetes, one of the most common diseases in the world. $\alpha$-glucosidase is a key enzyme responsible for the catabolism of carbohydrates, the inhibition of their activity has a vital role in decreasing the blood glucose level and represents one of the therapeutic approaches to fighting type 2 diabetes. In this work, we investigated the inhibitory effect of Salvia microphylla essential oils on $\alpha$-glucosidase. The $\alpha$-glucosidase inhibitor effects of essential oils from different parts of Salvia microphylla are presented in table 5. All essential oils (aerial parts, leaves and stems) exhibited a higher inhibitory activity on $\alpha$-Glucosidase, the most active being the stems essential oil ( $\mathrm{IC}_{50}: 19.36 \pm 2.35 \mu \mathrm{g} / \mathrm{mL}$ ), followed by aerial parts essential oil $\left(\mathrm{IC}_{50}: 41.34 \pm\right.$ $1.79 \mu \mathrm{g} / \mathrm{mL}$ ) and leaves essential oil ( $\mathrm{IC}_{50}: 50.25 \pm 1.75 \mu \mathrm{g} / \mathrm{mL}$ ). This biological activity was better than the one of acarbose $\left(\mathrm{IC}_{50}: 275.43 \pm 1.59 \mu \mathrm{g} / \mathrm{mL}\right.$ ). This is the first report on the antidiabetic effect of Salvia microphylla, but the results obtained for the evaluation of this activity for other species of the genus Salvia, showed similar or lower effects to ours $[23,24,70]$.

\section{Determination of Minimum Inhibitory Concentration (MIC) and Minimum Bactericidal (MBC) or Fungicidal (MFC) Concentrations}

A broth microdilution method in 96-well microplates was used to evaluate the antimicrobial activity of Salvia microphylla essential oils, against five Gram-negative, six Gram-positive bacteria and two yeast. The essential oils of different parts (aerial parts, leaves and stems) were investigated in concentrations between 0.10 $\mu \mathrm{L} / \mathrm{mL}$ and $26.66 \mu \mathrm{L} / \mathrm{mL}$ and the minimum bactericidal concentrations (MBC) and minimum fungicidal concentrations (MFC) were determined for susceptible strains. The MIC, MCB and MCF values of essential oils and standards (positive control) are shown in table 6.

According to the results obtained, all essential oils from different parts (aerial parts, leaves and stems) of Salvia microphylla exhibited antibacterial activity against all microorganisms except for Pseudomonas aeruginosa who presented total resistance.

This resistance is due to the presence of a very restrictive outer membrane barrier surrounding the Gram-negative bacteria cells [71].

Listeria monocytogeneswas sensitive to the essential oils of the aerial parts and leaves, providing a MIC value of $3.33 \mu \mathrm{L} / \mathrm{ml}$, but it was resistant to the essential oil of the stems. These results are consistent with research showing that EOs rich in 1,8-cineole demonstrated activity against Listeria monocytogenes [72]. This compound was found in aerial parts and leaves of Salvia microphylla with high concentrations (4.49 and $7.50 \%$, respectively), compared with stems essential oil (1.98 \% and MIC value of $26.66 \mu \mathrm{L} / \mathrm{ml})$. The essential oil isolated from stems showed strong antibacterial activity against all other bacteria with MIC values between $0.20-3.33 \mu \mathrm{L} / \mathrm{mL}$. Particularly, Enterobacter cloacae was the most sensitive to the stem essential oils with MIC of $0.20 \mu \mathrm{L} / \mathrm{ml}$, followed by Bacillus cereus, Salmonella abony with MIC of $0.83 \mu \mathrm{L} / \mathrm{ml}$ and Agrobacterium tumefaciens, Enterococcus faecalis and Staphylococcus aureus with MIC of $1.66 \mu \mathrm{L} / \mathrm{ml}$. As well as, the lowest activity was recorded for Escherichia coli, Micrococcus luteus and Bacillus subtilis with MIC of $3.33 \mu \mathrm{L} / \mathrm{ml}$.

However, the essential oils isolated from aerial parts and leaves showed high antibacterial activity against Bacillus subtilis with MIC of $0.41 \mu \mathrm{L} / \mathrm{ml}$ and $0.83 \mu \mathrm{L} / \mathrm{ml}$, respectively. while the lowest MIC value was $13.33 \mu \mathrm{L} / \mathrm{ml}$ for Salmonella abony, Enterobacter cloacae, Staphylococcus aureus and Bacillus cereus. 
Table 5. $\alpha$-glucosidase inhibitory assay of essential oils of Salvia microphylla aerial parts, leaves and stems.

\begin{tabular}{|c|c|c|c|c|c|c|c|c|}
\hline \multirow{2}{*}{ Samples } & \multicolumn{8}{|c|}{$\alpha$-glucosidase inhibitory assay } \\
\hline & $1.953 \mu \mathrm{g} / \mathrm{ml}$ & $3.906 \mu \mathrm{g} / \mathrm{ml}$ & $7.812 \mu \mathrm{g} / \mathrm{ml}$ & $15.625 \mu \mathrm{g} / \mathrm{ml}$ & $31.25 \mu \mathrm{g} / \mathrm{ml}$ & $62.5 \mu \mathrm{g} / \mathrm{ml}$ & $125 \mu \mathrm{g} / \mathrm{ml}$ & $\mathrm{IC}_{50} \mu \mathrm{g} / \mathrm{mL}$ \\
\hline Aerial parts & NA & NA & NA & $16.63 \pm 3.83$ & $28.21 \pm 3.07$ & $83.49 \pm 2.24$ & $97.54 \pm 1.01$ & $41.34 \pm 1.79$ \\
\hline Leaves & NA & NA & NA & $4.10 \pm 1.22$ & $28.18 \pm 3.10$ & $64.88 \pm 2.08$ & $87.85 \pm 0.35$ & $50.25 \pm 1.75$ \\
\hline Stems & NA & $23.48 \pm 2.36$ & $29.28 \pm 2.52$ & $47.29 \pm 4.26$ & $68.29 \pm 1.65$ & $87.58 \pm 0.06$ & $97.86 \pm 1.76$ & $19.36 \pm 2.35$ \\
\hline \multirow{2}{*}{ Acarbose ${ }^{\mathrm{R}}$} & $78.125 \mu \mathrm{g} / \mathrm{ml}$ & $156.25 \mu \mathrm{g} / \mathrm{ml}$ & $312.5 \mu \mathrm{g} / \mathrm{ml}$ & $625 \mu \mathrm{g} / \mathrm{ml}$ & $1250 \mu \mathrm{g} / \mathrm{ml}$ & $2500 \mu \mathrm{g} / \mathrm{ml}$ & $5000 \mu \mathrm{g} / \mathrm{ml}$ & \\
\hline & $27.43 \pm 2.18$ & $38.91 \pm 3.20$ & $54.86 \pm 1.79$ & $67.29 \pm 2.63$ & $80.19 \pm 1.66$ & $85.54 \pm 0.45$ & $91.05 \pm 0.72$ & $275.43 \pm 1.59$ \\
\hline
\end{tabular}

$\mathrm{IC}_{50}$ values are defined as the concentration of 50\% inhibition percentages and calculated by linear regression analysis and expressed as Mean \pm S.D of three parallel measurements. $R$ : reference compounds.

$N T$ : not tested.

$N A$ : not absorbance. 
In this study, the antibacterial activity of the essential oil isolated from stems against all tested microorganisms was greater than that of the other parts (aerial parts and leaves). It should be noted that some previous reports have described that the high activity might be attributed to the presence of $\alpha$-Eudesmol, $\beta$ Caryophyllene, $\gamma$-Eudesmol, Bicyclogermacrene, and the diterpenes (Abietatriene, Ferruginol) which are present in small amounts only in the stems essential oil [73]. The aerial parts essential oil showed bactericidal effects (MBC/MIC<4), for Bacillus subtilis, Micrococcus luteus, Staphylococcus aureus, Enterococcus faecalis and Escherichia coli. Besides, the leaves essential oil bactericidal effects were marked to all Gram-positive bacteria except for Listeria monocytogenes and Micrococcus luteus. However, the stems essential oil showed bacteriostatic effects for Bacillus subtilis and Salmonella abony because the MBC/MIC was higher than 4 [22, 74]. The strongest antifungal activity was observed against Candida albicans using the essential oil from Salvia microphylla aerial parts and leaves, with MIC values of $3.33 \mu \mathrm{L} / \mathrm{ml}$. Subsequent studies have confirmed that bicyclic monoterpenes $\alpha$-pinene and $\beta$-pinene showed considerable antifungal activity. These compounds were found in Salvia microphylla aerial parts and leaves at concentrations of 4.07-4.63\% and 2.29-2.63\%, respectively [73].

In general, the majority of compounds are often responsible for antibacterial activity. However, there are some studies where the whole combination of the major isolated components has a lower antibacterial activity than the essential oils. This can be explained by the presence of the synergistic effect between the various minority compounds of essential oils [71,75].

In comparison with a study carried out on the leaves essential oil of Salvia microphylla growing in Brazil, and collected in February 2007 [28], we observed that this essential oil exhibited an interesting antibacterial activity against Listeria, Pseudomonas aeruginosa, Staphylococcus aureus ATCC 25923 and Salmonella choleraesui, except for Escherichia coli which was resistant. This significant difference is probably due to the time of harvest, the collection region and the environmental factors. The antimicrobial activity of aerial parts and stems essential oils from Salvia microphylla has not been reported elsewhere. According to our results, Salvia microphylla essential oilscan be suggested in the treatment of human diseases and may be an interesting alternative to synthetic drugs.

Table 6. Antimicrobial activity of Salvia microphylla essential oils assayed using the broth microdilution method All tests were performed in duplicate and repeated twice.

\begin{tabular}{|c|c|c|c|c|c|c|c|c|}
\hline \multirow[b]{2}{*}{ Microorganisms } & \multicolumn{2}{|c|}{ Aerial parts } & \multicolumn{2}{|c|}{ Leaves } & \multicolumn{2}{|c|}{ Stems } & \multicolumn{2}{|c|}{ Standard } \\
\hline & MIC & $\begin{array}{l}\mathrm{MCB} / \\
\mathrm{MFC}\end{array}$ & MIC & $\begin{array}{l}\mathrm{MCB} / \\
\mathrm{MFC}\end{array}$ & MIC & $\begin{array}{l}\mathrm{MCB} / \\
\mathrm{MFC}\end{array}$ & MIC * & MIC** \\
\hline \multicolumn{9}{|c|}{ Gam-positive bacteria } \\
\hline $\begin{array}{c}\text { Bacillus subtilis ATCC } \\
6633\end{array}$ & 0.41 & 0.83 & 0.83 & 1.66 & 3.33 & 26.66 & 11.25 & NT \\
\hline $\begin{array}{c}\text { Bacillus cereus ATCC } \\
14975\end{array}$ & 13.33 & $>26.66$ & 13.33 & 13.33 & 0.83 & $>26.66$ & 22.50 & NT \\
\hline $\begin{array}{c}\text { Micrococcus luteus ATCC } \\
14110\end{array}$ & 13.33 & 26.66 & 6.66 & $>26.66$ & 3.33 & 13.33 & 11.25 & NT \\
\hline $\begin{array}{c}\text { Staphylococcus aureus } \\
\text { ATCC } 6538 \\
\end{array}$ & 13.33 & 13.33 & 13.33 & 13.33 & 1.66 & $>26.66$ & 22.50 & NT \\
\hline $\begin{array}{c}\text { Listeria monocytogenes } \\
\text { ATCC } 49594\end{array}$ & 3.33 & $>26.66$ & 3.33 & $>26.66$ & $>26.66$ & $>26.66$ & 22.50 & NT \\
\hline $\begin{array}{c}\text { Enterococcus faecalis } \\
\text { ATCC } 51299\end{array}$ & 6.66 & 13.33 & 6.66 & 13.33 & 1.66 & $>26.66$ & 11.25 & NT \\
\hline \multicolumn{9}{|c|}{ Gam-negativebacteria } \\
\hline $\begin{array}{l}\text { Escherichia coli ATCC } \\
25922\end{array}$ & 3.33 & 6.66 & 3.33 & $>26.66$ & 3.33 & $>26.66$ & 22.50 & NT \\
\hline $\begin{array}{c}\text { Agrobacterium } \\
\text { tumefaciens ATCC } 23308\end{array}$ & 3.33 & $>26.66$ & 1.66 & $>26.66$ & 1.66 & $>26.66$ & 11.25 & NT \\
\hline $\begin{array}{c}\text { Pseudomonas aeruginosa } \\
\text { ATCC } 25843\end{array}$ & NI & NI & NI & NI & NI & NI & 45.00 & NT \\
\hline
\end{tabular}




\begin{tabular}{|c|c|c|c|c|c|c|c|c|}
\hline $\begin{array}{c}\text { Salmonella abony ATCC } \\
\text { 14028 }\end{array}$ & 13.33 & $>26.66$ & 13.33 & $>26.66$ & 0.83 & 26.66 & 11.25 & NT \\
\hline $\begin{array}{c}\text { Enterobacter cloacae } \\
\text { ATCC 13047 }\end{array}$ & 13.33 & $>26.66$ & 13.33 & $>26.66$ & 0.20 & $>26.66$ & 11.25 & NT \\
\hline \multicolumn{7}{|c|}{ Yeast } \\
\hline $\begin{array}{c}\text { Candida albicans ATCC } \\
\text { 1023 }\end{array}$ & 3.33 & $>26.66$ & 3.33 & $>26.66$ & 6.66 & $>26.66$ & NT & 2.81 \\
\hline $\begin{array}{c}\text { Saccharomyces cerevisiae } \\
\text { ATCC 9763 }\end{array}$ & 13.33 & $>26.66$ & 13.33 & $>26.66$ & 13.33 & $>26.66$ & NT & 11,25 \\
\hline
\end{tabular}

MIC: minimum Inhibitory Concentration $(\mu \mathrm{L} / \mathrm{ml})$.

MCB. MFC: Minimum Bactericidal Concentration and Minimum Fungicidal Concentration $(\mu \mathrm{L} / \mathrm{ml})$.

Positive control: *Amoxicillin $(\mu \mathrm{g} / \mathrm{mL})$; **Ketoconazole $(\mu \mathrm{g} / \mathrm{mL})$

NI: no inhibition has been symbolized.

NT: not tested.

\section{Conclusion}

The results of this study showed that the chemical composition and biological activities (antioxidant, anticholinesterase, $\alpha$-glucosidase and antimicrobial activity) of essential oils of Salvia microphylla, varied significantly depending on the different parts of the plant extracted. Therefore, it may be concluded that essential oils of Salvia microphylla particular stems oil can be an important source of natural antioxidant compounds and may be used for neurodegenerative and antidiabetic chronic diseases. The antibacterial activity revealed that the inhibitory effect of the stems oil was very high as compared to the other parts against all the tested microorganisms, especially against Enterobacter cloacae. As well as the strongest antifungal activity was observed against Candida albicans by essential oils of aerial parts and leaves. Further studies are needed to evaluate this species for food, cosmetic and medical applications.

\section{References}

1. Bakkali, F.; Averbeck, S.; Averbeck, D.; Idaomar M. Food Chem. Toxicol. 2008, 46, 446-475. DOI: https://doi.org/10.1016/j.fct.2007.09.106

2. Hedge, I.C. Advances in Labiatae science. 1992, 7-17.

3. Kabouche, A.; Kabouche, Z. Stud. Nat. Prod. Chem. 2008, 753-833. DOI: https://doi.org/10.1016/S1572-5995(08)80017-8

4. Medjahed, F.; Merouane, A.; Saadi, A.; Bader, A.; Cioni, P.L.; Flamini, G. Chilean J. Agric. Res. 2016, 76, 195-200. DOI : http://dx.doi.org/10.4067/S0718-58392016000200009

5. Beladjila, K.A.; Berrehal, D.; Al-Aboudi, A.; Semra, Z.; Al-Jaber, H.; Bachari, K.; Kabouche, Z. Chem. Nat. Compd. 2018, 54, 581-583. DOI : https://doi.org/10.1007/s10600-018-2414-Z

6. Şenol, F.S.; Orhan, I.; Celep, F.; Kahraman, A.; Doğan, M.; Yilmaz, G.; Şener, B. Food Chem. 2010, 120, 34-43. DOI: https://doi.org/10.1016/j.foodchem.2009.09.066

7. Kamatou, G.P.P.; Makunga, N.P.; Ramogola, W.P.N.; Viljoen, A.M. J. Ethnopharmacol. 2008a, 119, 664-672. DOI: https://doi.org/10.1016/j.jep.2008.06.030

8. Kamatou, G.P.; Van Zyl, R.; Davids, H.; Van Heerden, F.; Lourens, A.; Viljoen, A.M. S. Afr. J. Bot. 2008b, 74, 238-243. DOI: https://doi.org/10.1016/j.sajb.2007.08.001

9. Kivrak, İ.; Duru, M.E.; Öztürk, M.; Mercan, N.; Harmandar, M.; Topçu, G. Food chem. 2009, 116, 470-479. DOI: https://doi.org/10.1016/j.foodchem.2009.02.069 
10. Tel, G.; Öztürk, M.; Duru, M.E.; Harmandar, M.; Topçu, G. Food Chem. Toxicol. 2010, 48, 31893193. DOI : https://doi.org/10.1016/j.fct.2010.08.020

11. Al-Jaber, H.I.; Al-Qudah, M.A.; Barhoumi, L.M.; Abaza, I.F.; Afifi, F.U. Nat. Prod. Res. 2012, 26, 1179-1187. DOI: https://doi.org/10.1080/14786419.2010.543901

12. Coisin, M.; Burzo, I.; Stefan, M.; Rosenhech, E.; Zamfirache, M.M. An. Stiint. Univ. Al. I. Cuza Iasi, Sect. II a. Biol. veget. 2012, 58, 51-58.

13. Marchev, A.; Ivanov, I.; Denev, P.; Nikolova, M.; Gochev, V.; Stoyanova, A.; Pavlov, A.; Georgiev, V. Journal of BioScience \& Biotechnology. 2015, 4.

14. Russo, A.; Formisano, C.; Rigano, D.; Cardile, V.; Arnold, N.A.; Senatore, F. Ind. Crops Prod. 2016, 83, 492-499. DOI: https://doi.org/10.1016/j.indcrop.2015.12.080

15. Temel, H.E.; Demirci, B.; Demirci, F.; Celep, F.; Kahraman, A.; Doğan, M.; Hüsnü Can Başer, K. J. Essent. Oil Res. 2016, 28, 322-331. DOI :https://doi.org/10.1080/10412905.2016.1159257

16. El Euch, S.K.; Hassine, D.; Cazaux, S.; Bouzouita, N.; Bouajila, J. S. Afr. J. Bot. 2019, 120, 253-260. DOI: https://doi.org/10.1016/j.sajb.2018.07.010

17. Süzgeç-Selçuk, S.; Özek, T.; Özek, G.; Yur, S.; Göger, F.; Gürdal, M.B.; Toplan, G.G.; Meriçli, A.H.; Başer, K.H.C. Rec. Nat. Prod. 2021, 15, 10-24. DOI: http://doi.org/10.25135/rnp.185.20.03.1579

18. Crespo, M.E.; Jimenez, J.; Navarro, C.; Zarzuelo, A. Planta Med. 1986, 52, 367-369. DOI: 10.1055/s2007-969187

19. Perry, N.S.L.; Houghton, P.J.; Sampson, J.; Theobald, A.E.; Hart, S.; Lis-Balchin, M.; Hoult, J.R.S.; Evans, P.; Jenner, P.; Milligan, S.; Perry, E.K. J. Pharm. Pharmacol. 2001, 53, 1347-1356. DOI: https://doi.org/10.1211/0022357011777846

20. Jirovetz, L.; Buchbauer, G.; Denkova, Z.; Slavchev, A.; Stoyanova, A.; Schmidt, E. Nutrition-Vienna. 2006, 30, 152.

21. Nikolić, M.; Jovanović, K.K.; Marković, T.; Marković, D.; Gligorijević, N.; Radulović, S.; Soković, M. Ind. Crops Prod. 2014, 61, 225-232. DOI: https://doi.org/10.1016/j.indcrop.2014.07.011

22. Adrar, N.; Oukil, N.; Bedjou, F. Ind. Crops Prod. 2016, 88, 112-119. DOI: https://doi.org/10.1016/j.indcrop.2015.12.007

23. Bahadori, M.B.; Dinparast, L.; Zengin, G.; Sarikurkcu, C.; Bahadori, S.; Asghari, B.; Movahhedin, N. Int. J. Food Prop. 2017a, 20, 1761-1772. DOI: https://doi.org/10.1080/10942912.2016.1218893

24. Bahadori, M.B.; Salehi, P.; Sonboli, A. Int. J. Food Prop. 2017b, 20, 2974-2981. DOI: https://doi.org/10.1080/10942912.2016.1263862

25. Valdés, B.; Martín, M.; Díaz, Z. Bot. Macaron. 1995, 21, 107-120.

26. Jenks, A.A.; Kim, S.-C. J. Ethnopharmacol. 2013, 146, 214-224. DOI: https://doi.org/10.1016/j.jep.2012.12.035

27. Béjar, E.; Bussmann, R.; Roa, C.; Sharon, D. Latin Herbal Press, San Diego. 2001.

28. Lima, R.K.; dasGraças Cardoso, M.; Andrade, M.A.; Guimarães, P.L.; Batista, L.R.; Nelson, D.L. J. Am. Oil Chem. Soc. 2012, 89, 523-528. DOI: https://doi.org/10.1007/s11746-011-1938-1

29. Romo-Asunción, D.; Ávila-Calderón, M.A.; Ramos-López, M.A.; Barranco-Florido, J.E.; RodríguezNavarro, S.; Romero-Gomez, S.; Aldeco-Pérez, E.J.; Pacheco-Aguilar, J.R.; Rico-Rodríguez, M.A. Fla. Entomol. 2016, 345-351. DOI: https://www.jstor.org/stable/24891070

30. Aydoğmuş, Z.; Yeşillyurt, V.; Topcu, G. Nat. Prod. Res. 2006, 20, 775-781. DOI: https://doi.org/10.1080/14786410500462843

31. Esquivel, B.; Cardenas, J.; Rodriguez-Hahn, L.; Ramamoorthy, T. J. Nat. Prod. 1987, 50, 738-740. DOI: https://doi.org/10.1021/np50052a029

32. Esquivel, B.; del Socorro Martínez, N.; Cárdenas, J.; Ramamoorthy, T.; Rodríguez-Hahn, L. Planta Med. 1989, 55, 62-63. DOI: 10.1055/s-2006-961827 
33. Bautista, E.; Toscano, R.A.; Ortega, A. Org. Lett. 2013, 15, 3210-3213. DOI: https://doi.org/10.1021/ol401022c

34. Bautista, E.; Toscano, R.n.A.; Ortega, A. J. Nat. Prod. 2014, 77, 1088-1092. DOI: https://doi.org/10.1021/np4009893

35. Chialva, F.; Monguzzi, F.; Manitto, P. J. Essent. Oil Res. 1992, 4, 447-455. DOI: https://doi.org/10.1080/10412905.1992.9698108

36. Koutsaviti, A.; Antonopoulou, V.; Vlassi, A.; Antonatos, S.; Michaelakis, A.; Papachristos, D.P.; Tzakou, O. Journal of pest science. 2018, 91, 873-886. DOI: https://doi.org/10.1007/s10340-017$\underline{0934-0}$

37. Marchioni, I.; Najar, B.; Ruffoni, B.; Copetta, A.; Pistelli, L.; Pistelli, L. Plants. 2020, 9, 691. DOI: https://doi.org/10.3390/plants9060691

38. National Committee for Clinical Laboratory Standards (NCCLS), Wayne, PA. New York. M2-A6. 1997.

39. Clinical and laboratory standards institute. Quality Control Minimal Inhibitory Concentration (MIC) Limits for Broth Microdilution and MIC Interpretive Breakpoints. Supplement M27-S2. 2006.

40. Joulain, D.; König, W. Verlag: EB-Verlag, Hamburg, Germany. 1998.

41. Adams, R.P. Quadruple mass spectroscopy. Allured Publishing Corporation, Carol. Stream, IL, USA, 2001, 456.

42. Van Den Dool, H.; Kratz, P. D. A. J. Chromatogr. A. 1963, 11, 463-471.

43. Goldschmidt, S.; Renn, K. Ber. Dtsch. Chem. Ges. A. B. 1922, 55, 628-643. DOI: https://doi.org/10.1002/cber.19220550308

44. Osman, A.M. Biochem. Biophys. Res. Commun. 2011, 412, 473-478. DOI: https://doi.org/10.1016/j.bbrc.2011.07.123

45. Passari, A. K.; Leo, V. V.; Singh, G.; Samanta, L.; Ram, H.; Siddaiah, C. N.; Hashem, A.; Al-Arjani, A.-B. F.; Alqarawi, A. A.; Fathi Abd_Allah, E. Int. J. Mol. Sci. 2020, 21, 7364. DOI: https://doi.org/10.3390/ijms21197364

46. Ražná, K.; Sawinska, Z.; Ivanišová, E.; Vukovic, N.; Terentjeva, M.; Stričík, M.; Kowalczewski, P. Ł.; Hlavačková, L.; Rovná, K.; Žiarovská, J. Int. J. Mol. Sci. 2020, 21, 3087. DOI: https://doi.org/10.3390/ijms21093087

47. Mishra, K.; Ojha, H.; Chaudhury, N.K. Food Chem. 2012, 130, 1036-1043. DOI: https://doi.org/10.1016/j.foodchem.2011.07.127

48. Re, R.; Pellegrini, N.; Proteggente, A.; Pannala, A.; Yang, M.; Rice-Evans, C. Free Radicals Biol. Med. 1999, 26, 1231-1237. DOI: https://doi.org/10.1016/S0891-5849(98)00315-3

49. Apak, R.; Güçlü, K.; Özyürek, M.; Karademir, S.E. J. Agric. Food Chem. 2004, 52, 7970-7981. DOI: https://doi.org/10.1021/jf048741x

50. Oyaizu, M. Jpn. J. Nutr. Diet. 1986, 44, 307-315. DOI : https://doi.org/10.5264/eiyogakuzashi.44.307

51. Ellman, G.L.; Courtney, K.D.; Andres Jr, V.; Featherstone, R.M. Biochem. Pharmacol. 1961, 7, 8895. DOI: https://doi.org/10.1016/0006-2952(61)90145-9

52.Lordan, S.; Smyth, T.J.; Soler-Vila, A.; Stanton, C.; Ross, R.P. Food Chem. 2013, 141, 2170-2176. DOI: https://doi.org/10.1016/j.foodchem.2013.04.123

53. Amrani, A.; Mecheri, A.; Bensouici, C.; Boubekri, N.; Benaissa, O.; Zama, D.; Benayache, F.; Benayache, S. Biocatal. Agric. Biotechnol. 2019, 20, 101209. DOI: https://doi.org/10.1016/j.bcab.2019.101209

54. Approved Standard-National Committee for Clinical Laboratory Standards Wayne, PA. 2008, 28, M27-A3. 
55. Approved Standard-Tenth Edition; Document M07-A10; Clinical and Laboratory Standards Institute: Wayne, PA. 2015.

56. Cutillas, A.B.; Carrasco, A.; Martinez-Gutierrez, R.; Tomas, V.; Tudela, J. Mol. 2017, 22, 1382. DOI: https://doi.org/10.3390/molecules22081382

57. Balouiri, M.; Sadiki, M.; Ibnsouda, S.K. J. Pharm. Anal. 2016, 6, 71-79. DOI: https://doi.org/10.1016/j.jpha.2015.11.005

58. Martínez-Francés, V.; Hahn, E.; Ríos, S.; Rivera, D.; Reich, E.; Vila, R.; Cañigueral, S. Front. Pharmacol. 2017, 8, 467. DOI: https://doi.org/10.3389/fphar.2017.00467

59. Mata, A.; Proença, C.; Ferreira, A.; Serralheiro, M.; Nogueira, J.; Araújo, M. Food Chem. 2007, 103, 778-786. DOI: https://doi.org/10.1016/j.foodchem.2006.09.017

60. Ruberto, G.; Baratta, M.T. Food Chem. 2000, 69,167-174. DOI: https://doi.org/10.1016/S0308$\underline{8146(99) 00247-2}$

61. Loizzo, M.R.; Tundis, R.; Conforti, F.; Menichini, F.; Bonesi, M.; Nadjafi, F.; Frega, N.G.; Menichini, F. Nutr. Res. 2010, 30, 823-830. DOI: https://doi.org/10.1016/j.nutres.2010.09.016

62. Fu, Z.; Wang, H.; Hu, X.; Sun, Z.; Han, C. J. Appl. Pharm. Sci. 2013, 3, 122-127. DOI: 10.7324/JAPS.2013.3723

63. Vladimir-Knezevic, S.; Blazekovic, B.; Kindl, M.; Vladic, J.; Lower-Nedza, A.D.; Brantner, A.H. Mol. 2014, 19, 767-782. DOI: https://doi.org/10.3390/molecules19010767

64. Perry, N.S.; Houghton, P.J.; Jenner, P.; Keith, A.; Perry, E.K. Phytomedicine. 2002, 9, 48-51. DOI: https://doi.org/10.1078/0944-7113-00082

65. Savelev, S.U.; Okello, E.J.; Perry, E.K. Phytother. Res. 2004, 18, 315-324. DOI: https://doi.org/10.1002/ptr.1451

66. Duru, M.E.; Tel, G.; Öztürk, M.; Harmandar, M. Rec. Nat. Prod. 2012, 6, 175-179.

67. Salinas, M.; Bec, N.; Calva, J.; Ramírez, J.; Andrade, J.M.; Larroque, C.,; Vidari, G.; Armijos, C. Rec. Nat. Prod. 2020, 14, 276-285. DOI: http://doi.org/10.25135/rnp.164.19.07.1342

68. Savelev, S.; Okello, E.; Perry, N.S.; Wilkins, R.M.; Perry, E.K. Pharmacol., Biochem. Behav. 2003, 75, 661-668. DOI: https://doi.org/10.1016/S0091-3057(03)00125-4

69. Loizzo, M.R.; Menichini, F.; Tundis, R.; Bonesi, M.; Conforti, F.; Nadjafi, F.; Statti, G.A.; Frega, N.G.; Menichini, F. J. Oleo Sci. 2009, 58, 443-446. DOI: https://doi.org/10.5650/jos.58.443

70. Bahadori, M.B.; Valizadeh, H.; Asghari, B.; Dinparast, L.; MoridiFarimani, M.; Bahadori, S. J. Funct. Foods. 2015, 18, 727-736. DOI:https://doi.org/10.1016/j.jff.2015.09.011

71. Burt, S. Int. J. Food Microbiol. 2004, 94, 223-253. DOI: https://doi.org/10.1016/j.ijfoodmicro.2004.03.022

72. Mourey, A.; Canillac, N. Food Control. 2002, 13, 289-292. DOI: https://doi.org/10.1016/S0956$\underline{7135(02) 00026-9}$

73. Koroch, A. R.; Juliani, H. R.; Zygadlo, J. A. Flavours Fragrances. 2007, 87-115. DOI: https://doi.org/10.1007/978-3-540-49339-6_5

74. Traoré, Y.; Ouattara, K.; Yéo, D.; Doumbia, I.; Coulibaly, A. J. Appl. Biosci. 2012, 58, 4234-4242.

75. Mastelic, J.; Politeo, O.; Jerkovic, I.; Radosevic, N. Chem. Nat. Compd. 2005, 41, 35-40. DOI: https://doi.org/10.1007/s10600-005-0069-z 